\title{
AR DIDŽIAUSIO INTENSYVUMO EKSCENTRINIS- KONCENTRINIS KRŪVIS PANAŠIAI VEIKIA VYRŲ IR MOTERŲ MOTORINĘ SISTEMĄ?
}

\author{
Giedrius Gorianovas $^{1}$, Vytautas Streckis ${ }^{1}$, Albertas Skurvydas ${ }^{1}$, Sigitas Kamandulis ${ }^{1}$, \\ Vaidas Mickevičius ${ }^{2}$ \\ Lietuvos kūno kultūros akademija ${ }^{1}$, Kauno technikos kolegija ${ }^{2}$, Kaunas, Lietuva
}

\begin{abstract}
Giedrius Gorianovas. Lietuvos kūno kultūros akademijos doktorantas. Mokslinių tyrimų kryptis — ivvairaus amžiaus žmonių raumenų pažeidą
\end{abstract} sukeliančių fiziniu pratimų poveikis centriniam, periferiniam nuovargiui ir atsigavimui.

\section{SANTRAUKA}

Tyrimo tikslas — nustatyti, ar ekscentrinis-koncentrinis krūvis panašiai veikia vyru ir moteru motorinę sistema.

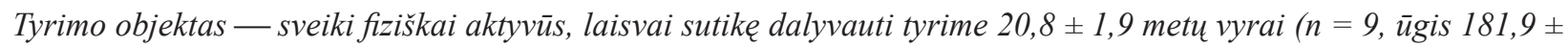
$5,9 \mathrm{~cm}$, svoris $82,6 \pm 10,0 \mathrm{~kg}$ ) ir 22,0 $\pm 3,9$ metu moterys ( $=9$, ügis 166,6 $\pm 5,2 \mathrm{~cm}$, svoris $62,6 \pm 5,5 \mathrm{~kg}$ ).

Tyrimo metu buvo registruojami netiesioginiai raumenu pažeidos rodikliai: prieš krūvi, praèjus 10, 60 min, 24 ir 48 h po jo - valingu (maksimalioji valinga jega (MVJ)) ir nevalingu (20 ir $100 \mathrm{~Hz}$ elektrostimuliacijos sukelta) keturgalvio šlaunies raumens susitraukimu jèga raumeniui esant ilgam (IR) ir trumpam (TR) (kai kelio sulenkimo kampas - 90 ir $60^{\circ}$ ). Pagal $20 / 100 \mathrm{~Hz}$ santyki vertinamas mažu dažniu nuovargis (MDN), matuojamas šuolio aukštis (h) iš fiksuotos padèties; nustatomas kreatinkinazès aktyvumas prieš krūvi, praèjus 24 ir 48 h po jo, vertinamas subjektyvus raumenu skausmas po krūvio praèjus 12, 24 ir 48 h. Fizinis krūvis - 100 šuoliu kas 20 s, nušokant nuo $40 \mathrm{~cm}$ pakylos ir pritūpus $90^{\circ}$ kampu pašsokant maksimaliai aukštyn. Krūvio metu buvo registruojamas kelio sulenkimo kampas (KSK).

Po krūvio vyru ir moteru nuovargio rodikliai iš esmès nesiskyrè ( $p>0,05)$ : lyginant su reikšmèmis prieš krūvi, kai raumuo buvo ilgas (IR), vyru MVJ buvo 62,9 $\pm 14,1 \%$, o TR sieke $64,4 \pm 14,1 \%$, moteru $-71,7 \pm 8,3$ ir $65,7 \pm$ 9,3\%; šuolio aukštis - vyru buvo 83,6 7,2\%, moteru - 80,3 $\pm 6,5 \%$; MDN - vyru 59,3 $\pm 20,9 \%$ esant IR ir $33,8 \pm 14,8 \%$ esant TR, moteru atitinkamai $68,7 \pm 17,5 \%$ ir $43,4 \pm 16,4 \%$. Subjektyvus raumenu skausmas abieju tirtu grupiu buvo panašus ( $p>0,05)$. Valingu ir nevalingu raumenu susitraukimo jègos kitimas atsigavimo metu nuo lyties nepriklausè. Nustatyta, kad praèjus 48 h po krūvio moteru kreatinkinazès aktyvumas, lyginant su vyrais, yra mažesnis $(p<0,05)$.

Išvados: vyru ir moteru raumenu nuovargis ir atsigavimo kaita po didžiausio intensyvumo kartotinio ekscentrinio-koncentrinio krūvio iš esmès nesiskiria, tačiau moteru kreatinkinazès aktyvumas po krūvio praèjus 48 h yra mažesnis.

Raktažodžiai: lytis, ekscentrinis-koncentrinis krūvis, nuovargis ir atsigavimas.

\section{IVADAS}

$\Lambda$ tliekant izometrinius pratimus moterų koju raumenų nuovargis, lyginant su vyrais, yra mažesnis (Yoon et al., 2007), o po ekscentrinių jègos pratimų, atliekamų izokinetiniu dinamometru, alkūnès lenkiamujų raumenų sumažèjusi maksimalioji valinga jèga ir subjektyvus skausmas lyties požiuriu nesiskiria (Sayers, Clarkson, 2001; Hubal et al., 2008). Tirtoje didelèje grupejje (testuota net 100 vyru ir moterų) ketvirtadalio tiriamų- jų jëga sumažèjo net $70 \%$, daugiausia - moteru (Sayers, Clarkson, 2001). Vis dèlto kai kurie lyčiai būdingi raumenu metabolizmo procesai turètų rodyti priešingus dalykus. Kodèl? Teorini mūsų atlikto tyrimo pagrindą sudaro tai, kad moteriškasis hormonas estradiolis, turintis antioksidaciniu savybių bent jau gyvūnų raumenims, veikia membranos pralaidumą (Bar et al., 1988). Dèl jo gali sumažèti kreatinkinazès aktyvumas (Feng et al., 
2004) ir sukelti uždegimą (Kendal, Eston, 2002; Tiidus, 2000), kurio raiška akivaizdi praejjus 24 valandoms po krūvio ir yra susijusi su antriniu jègos mažèjimu (Clarkson, Hubal, 2002; Byrne et al., 2004). Estradiolio koncentracija moterų organizme priklauso nuo menstruacinio ciklo ir didžiausia folikulinèje fazèje (Kendal, Eston, 2002). Taigi iškèlème hipotezę, kad moteru raumenys turètu būti atsparesni raumenų pažeidai nei vyrų, todèl mūsų tyrimo tikslas - remiantis netiesioginiais raumenu pažeidos rodikliais nustatyti, ar didžiausio intensyvumo ekscentrinis-koncentrinis krūvis panašiai veikia vyrų ir moterų motorinę sistemą.

\section{TYRIMO METODIKA}

Tiriamieji - sveiki fiziškai aktyvūs, laisvai sutikę dalyvauti tyrime $20,8 \pm 1,9$ metu vyrai ( $\mathrm{n}=9$, ūgis $181,9 \pm 5,9 \mathrm{~cm}$, kūno mase $82,6 \pm$ $10,0 \mathrm{~kg})$ ir $22,0 \pm 3,9$ metu moterys $(\mathrm{n}=9$, ūgis $166,6 \pm 5,2 \mathrm{~cm}$, kūno masè $62,6 \pm 5,5 \mathrm{~kg}$ ), kurie iki eksperimento ne mažiau kaip šešis mènesius nesitreniravo. Tiriamieji buvo supažindinti su tyrimo tikslais, procedūromis ir galimais nepatogumais. Norą dalyvauti tyrime jie patvirtino raštu. Tyrimas atliktas laikantis $1975 \mathrm{~m}$. Helsinkio deklaracijoje priimtų principų dèl eksperimentų su žmonėmis etikos. Eksperimento protokolas aprobuotas KMU bioetikos komisijoje. Fizini krūvị moterys atliko folikulinèje menstruacinio ciklo fazèje.

Kojos tiesiamųjų raumenų valingų ir nevalingų susitraukimų jègos rodiklių nustatymas. Valingus raumenų susitraukimo izometrinès jègos rodiklius (maksimaliają valingą jègą (MVJ)) matavome naudodami specializuotą testavimui ir reabilitacijai skirtą izokinetini dinamometrą (Biodex Medical System 3 PRO, sertifikuotą ISO 9001 EN 46001), nevalingus - naudojant elektrostimuliatoriu (Medicor MG440, Vengrija).

Valingų ir nevalingų susitraukimų izometrinè jèga buvo nustatoma raumeniui esant ilgam (IR) ir trumpam (TR) (kai kelio sulenkimo kampas 90 ir $60^{\circ}$ ). Tiriamajam atsisédus ì specialią kẻdę, dešinè koja fiksuojama prie dinamometro pritvirtintu papildomu kelio įtaisu. Nustačius anatominę kelio sąnario ašĭ, tiriamasis apjuosiamas pečių kryžminiais ir liemens bei šlaunies skersiniais diržais. Blauzda, sutvirtinta diržu su sagtimi, apjuosiama apatiniame trečdalyje $-4 \mathrm{~cm}$ virš kulnakaulio gumburo. Nustatoma testuojamos kojos anatominè lenkimo amplitudè (ištiesus $\left(0^{\circ}\right)$ ir sulenkus blauzdą per kelio sąnari); ji pasveriama $70 \pm 1^{\circ}$ padèties (matuojant MVJ, kai kelio sulenkimo kampas 90 ir $60^{\circ}$ ).
Nevalingu susitraukimu jègoms nustatyti ant keturgalvio šlaunies raumens distalaus ir proksimalaus trečdalių buvo dedami paviršiniai, $6 \times 11 \mathrm{~cm}$ guminiai elektrodai, sudrèkinti specialiu geliu (Streckis et al., 2007). Raumuo buvo stimuliuojamas 20 ir $100 \mathrm{~Hz}$ dažniais. Pagal 20 / $100 \mathrm{~Hz}$ pokyčius nustatomas mažų dažnių nuovargis (Skurvydas, Streckis, 1998; Skurvydas et al., 1999).

Šoklumo testavimas. Kontroliniai ir fizinio krūvio metu atlikti šuoliai buvo matuojami naudojant daugiakomponentę jëgos platformą (Kistler 9286 A, Šveicarija). Remiantis C. Bosco ir P. Komi (Bosco, Komi, 1979) metodika skaičiuojamas vertikalaus šuolio aukštis (h).

Kelio sąnario sulenkimo kampo nustatymas. Kelio sulenkimo kampui (KSK) šuoliavimo metu matuoti buvo naudojamas mobilusis goniometraselektromiografas Biometrics Ltd, skirtas žmogaus judesių dinaminèms ir kinematinėms ypatybėms nustatyti. Prietaisas buvo pritvirtinamas prie tiriamojo liemens, apjuosus ji diržu, goniometro-elektromiografo biosensoriai tiriamajam uždedami lygiagrečiai kelio sąnariui ant šoninès dalies, vieną galą tvirtinant ant keturgalvio šlaunies raumeninès fascijos, kitą ant blauzdos raumenų ir fiksuojami drègmei atspariu pleistru. Tiriamasis atsistodavo ant kontaktinès platformos tiesiomis kojomis tam, kad būtu galima nustatyti nulines goniometro biosensoriaus reikšmes.

Subjektyvaus raumenų skausmo vertinimas. Raumenų skausmą tiriamieji vertino dešimties balų sistema, tyrejjui pateikus vertinimo lentelę (Jones et al., 1987).

Kreatinkinazès (CK) aktyvumo kraujo serume nustatymas. Kreatinkinazès aktyvumas buvo nustatomas automatiniu biocheminiu analizatoriumi Spotchem 2 (2003, Japonija) iš tiriamojo piršto paèmus kapiliarinio kraujo. Prietaiso matavimo galimybès 50-2000 IU/L (0,83-33,34 $\mu \mathrm{kat} / \mathrm{l})$.

Tyrimo eiga. Tyrimas atliktas Lietuvos kūno kultūros akademijos Žmogaus motorikos, raumenu fiziologijos laboratorijoje. Pirmą dieną tiriamieji buvo supažindinti su tyrimo protokolu, nustatoma stimuliacinè itampa. Kitą dieną tiriamiesiems taikytas toks krūvis: 100 nušokimu (pritupiant $90^{\circ}$ kampu) kas $20 \mathrm{~s}$ nuo $40 \mathrm{~cm}$ pakylos ir pašokant kiek galima aukštyn. Fizinio krūvio metu buvo registruojamas kelio sulenkimo kampas ir šuolio aukštis. Tiriant buvo nustatomi šie netiesioginiai raumenu pažeidos rodikliai:

1. Kreatinkinazès aktyvumas kraujo serume prieš krūvit, praejus 24 ir $48 \mathrm{~h}$ po jo.

2. Kontroliniai šuoliai iš fiksuotos padèties (3 bandymai) — prieš krūvị, iškart po jo, praè- 
jus 1, 24, 48 h po krūvio (îskaitomas geriausias šuolio rezultatas).

3. $20 \mathrm{~Hz}$ ir $100 \mathrm{~Hz}$ elektrostimuliacija bei MVJ matavimai raumeniui esant ilgam ir trumpam prieš krūvị, praejjus 10 min, 1, 24, 48 h po jo;

4. Subjektyvus raumenų skausmas įvertinamas praejus 12, 24 ir $48 \mathrm{~h}$ po krūvio;

Prieš fizini krūvị, po kreatinkinazès bei valingos ir nevalingos jègos matavimų, tiriamieji atliko 10 min trukmès pramankštą (veloergometrini krūvį, pulsas $110-150 \mathrm{tv} . / \mathrm{min}$ ).

Matematinè statistika. Skaičiavome aritmetinị duomenų vidurki, standartinį nuokrypi. Skirtumų tarp aritmetinių vidurkių reikšmingumas buvo nustatomas $t$ testu porinems ir nepriklausomoms imtims. Taikème dviejų veiksnių dispersinę analizę norèdamit nustatyti lyties ir laiko poveiki registruojamiems rodikliams. Skirtumai tarp aritmetiniu vidurkių buvo laikomi reikšmingais, kai paklaida mažesnè nei $5 \%(\mathrm{p}<0,05)$. Skaičiavimai atlikti naudojant statistines Microsoft ${ }^{\circledR}$ Excel 2003 ir SPSS programas.

\section{REZULTATAI}

Tyrimo duomenys parodè, kad prieš krūvi didesnès vyrų nei moteru $(\mathrm{p}<0,05)$ tiek šuolio aukščio, tiek maksimaliosios valingos jẻgos reikšmès (žr. lent.).

Atlikus 100 šuolių, statistiškai reikšmingai sumažėjo abiejų lyčių tiek valingos (3 pav.), tiek elektrostimuliacija sukeltos nevalingos mažų ir didelių dažnių jègos santykis esant IR bei TR. Pasireiškè mažų dažnių (P 20 / P 100) nuovargis ( $\mathrm{p}<0,05,4$ pav.), kuris praejjus $48 \mathrm{~h}$ po krūvio neišnyko $(p<0,05)$. Sumažejo šuolio aukštis

\begin{tabular}{|c|c|c|c|c|c|c|c|c|}
\hline $\begin{array}{l}\text { Lentelè. Vyrų ir moterų pradi- } \\
\text { niai šuolio aukščio (h), maksi- } \\
\text { maliosios valingos (MVJ), ma- } \\
\text { žais (P 20) ir dideliais (P 100) }\end{array}$ & $\begin{array}{c}\text { Funkciniai } \\
\text { rodikliai }\end{array}$ & $\begin{array}{c}\check{\text { Šuolio }} \\
\text { aukštis h, cm }\end{array}$ & $\begin{array}{c}\text { MVJ } \\
\left(90^{\circ}\right), \\
\mathbf{N} \cdot \mathbf{m}\end{array}$ & $\begin{array}{c}\text { MVJ } \\
\left(60^{\circ}\right), \\
\mathbf{N} \cdot \mathbf{m}\end{array}$ & $\begin{array}{c}\text { P 20 } \\
\left(90^{\circ}\right), \\
\mathbf{N} \cdot \mathbf{m}\end{array}$ & $\begin{array}{l}\text { P 20 } \\
(60), \\
N \cdot m\end{array}$ & $\begin{array}{c}\text { P } 100 \\
\left(90^{\circ}\right), \\
\mathrm{N} \cdot \mathrm{m}\end{array}$ & $\begin{array}{c}\mathrm{P} 100 \\
\left(60^{\circ}\right), \\
\mathrm{N} \cdot \mathrm{m}\end{array}$ \\
\hline $\begin{array}{l}\text { stimuliavimo dažniais sukeltos } \\
\text { jègos reikšmès raumeniui esant }\end{array}$ & Vyrai & $35,53 \pm 5,1$ & $310 \pm 62$ & $262 \pm 44$ & $141 \pm 42$ & $149 \pm 43$ & $187 \pm 51$ & $226 \pm 48$ \\
\hline & Moterys & $24,31 \pm 3,4$ & $174 \pm 59$ & $170 \pm 30$ & $80 \pm 21$ & $100 \pm 27$ & $102 \pm 28$ & $142 \pm 30$ \\
\hline Pastaba. $\mathrm{p}<0,05-$ skirtumo pa- & $\mathrm{p}$ & $\mathrm{p}<0,05$ & $\mathrm{p}<0,05$ & $\mathrm{p}<0,05$ & $\mathrm{p}<0,05$ & $\mathrm{p}<0,05$ & $\mathrm{p}<0,05$ & $\mathrm{p}<0,05$ \\
\hline
\end{tabular}

1 pav. Vyrų ir moterų šuolio aukščio kitimas po krūvio ir atsigavimo metu

Pastaba. Šuolio aukštis procentais praejjus $1 \mathrm{~min}$ (A 1), 60 min (A 60), 24 (A 24) ir 48 h (A 48) po krūvio; * - p $<0,05$, lyginant su reikšme prieš krūvi.

2 pav. Vyrų ir moterų kelio sulenkimo kampo (KSK) vidutinės reikšmės po krūvio

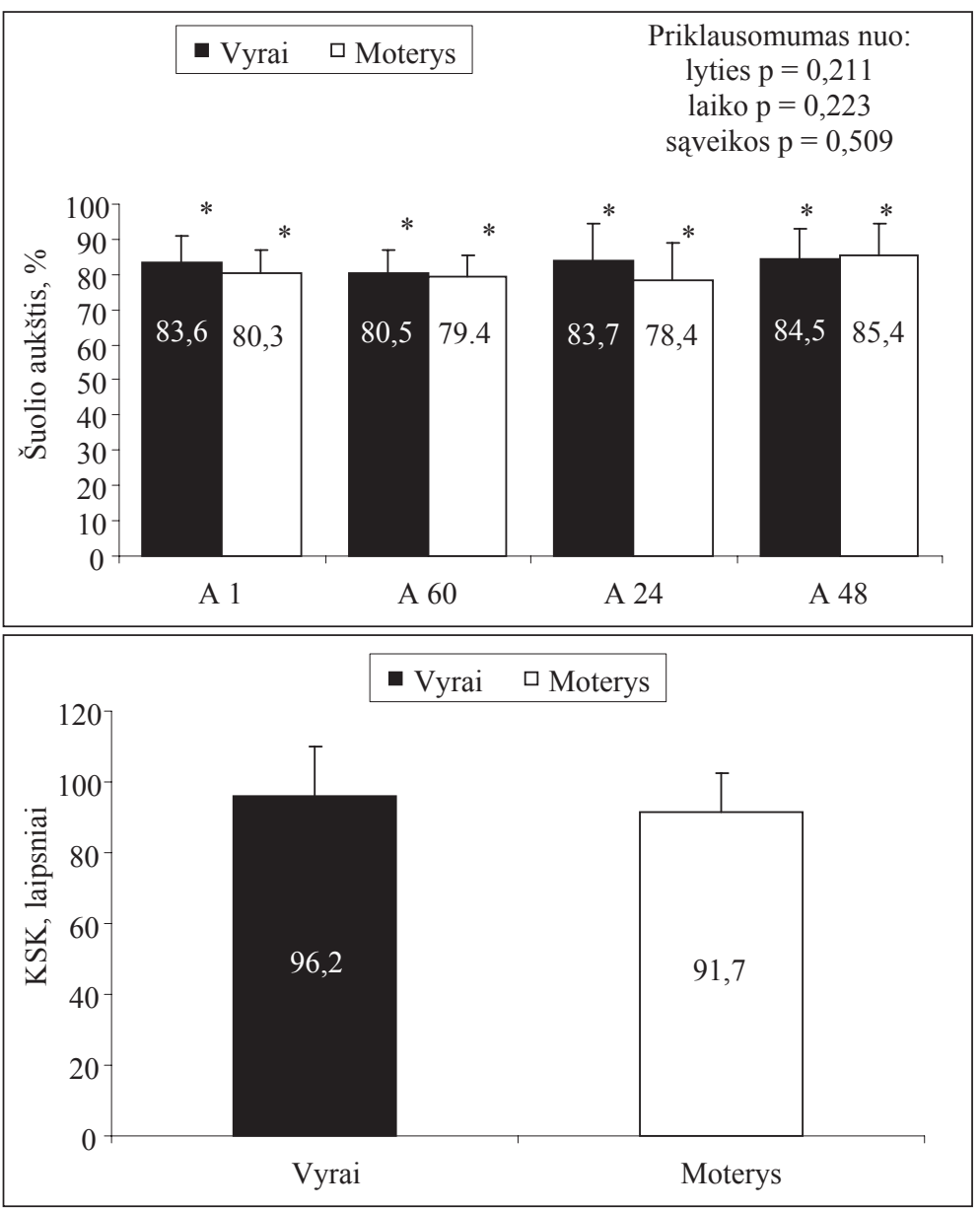



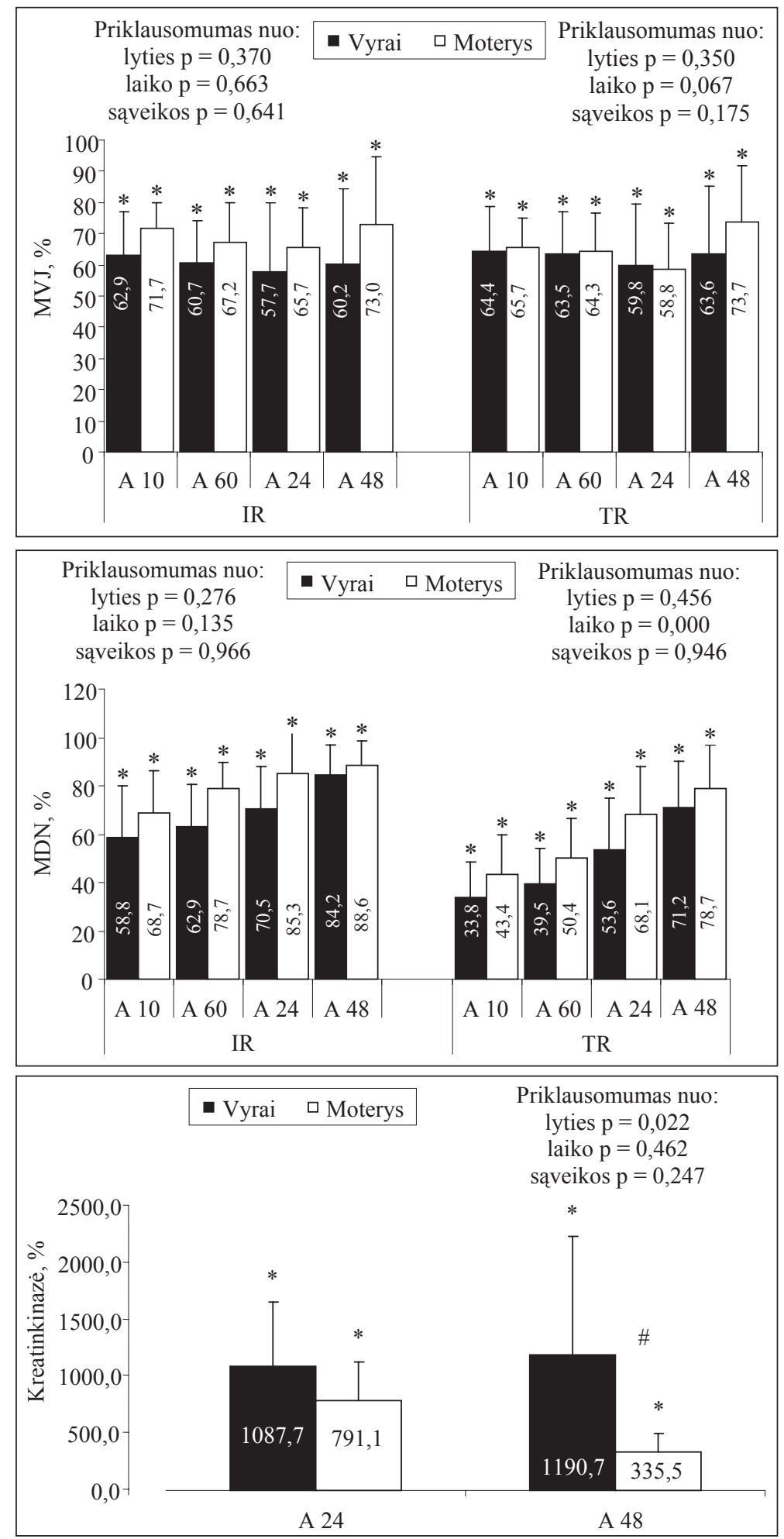

3 pav. Vyrų ir moterų maksimaliosios valingos jėgos (MVJ) kitimas raumeniui esant ilgam (IR) ir trumpam (TR) (kai kelio sulenkimo kampas $90^{\circ}$ ir $60^{\circ}$ )

Pastaba. MVJ procentais praèjus $10 \mathrm{~min}$ (A 10), 60 min (A 60), 24 h (A 24) ir 48 h (A 48) po krūvio; * $\mathrm{p}<0,05$, lyginant su reikšme prieš krūvị.

4 pav. Vyrų ir moterų mažų dažnių nuovargio (MDN) kitimas raumeniui esant ilgam (IR) ir trumpam (TR) (kai kelio sulenkimo kampas $90^{\circ}$ ir $60^{\circ}$ )

Pastaba. MDN procentais praejus $10 \mathrm{~min}$ (A 10), 60 min (A 60), 24 h (A 24) ir 48 h (A 48) po krūvio; * $\mathrm{p}<0,05$, lyginant su reikšmėmis prieš krūvị.

5 pav. Vyrų ir moterų kreatinkinazės (CK) aktyvumo kitimas po krūvio

Pastaba. CK aktyvumas procentais praejus $24 \mathrm{~h}$ (A 24) ir 48 h (A 48) po krūvio; * - p $<0,05$, lyginant su reikšme prieš krūvị; \#- palyginus reikšmes tarp vyrų ir moterų.

( $\mathrm{p}<0,05,1$ pav.) ir praejjus $48 \mathrm{~h}$ po krūvio neatsigavo $(\mathrm{p}<0,05)$. Nustateme, kad praejjus 24 ir $48 \mathrm{~h}$ po krūvio padidejjo $(\mathrm{p}<0,05)$ abieju tirtu grupiu CK aktyvumas (5 pav.). Praejjus 12 h po krūvio vyrai ir moterys pajuto raumenų skausmą, kuris po $24 \mathrm{~h}$ padidejo $(\mathrm{p}<0,05,6$ pav. $)$

Neaptikta statistiškai reikšmingo skirtumo po krūvio ( $\mathrm{p}>0,05, t$ testas taikytas nepriklausomoms imtims) tarp vyrų ir moterų šuolio aukščio (1 pav.), MVJ (3 pav.) ir MDN (4 pav.) esant IR ir
TR bei subjektyviam raumenu skausmui (6 pav.). Moteru CK aktyvumas, lyginant su vyrais, praejus $48 \mathrm{~h}$ po krūvio (5 pav.) buvo mažesnis ( $\mathrm{p}<0,05, t$ testas taikytas nepriklausomoms imtims).

Dviejų veiksnių dispersinè analizé parodè, kad valingu ir nevalingų raumenų susitraukimo jèga (3, 4 pav.), šuolio aukštis (1 pav.) ir subjektyvus raumenu skausmas ( 6 pav.) atsigavimo metu nepriklauso nuo lyties $(\mathrm{p}=0,145-0,760)$, lyties ir laiko sąveikos $(p=0,175-0,966)$, išskyrus CK 
6 pav. Vyrų ir moterų subjektyvaus raumenų skausmo kitimas po krūvio
Pastaba. Raumenu skausmas balais praejus $12 \mathrm{~h}$ (A 12), 24 h (A 24) ir 48 h (A 48) po krūvio.

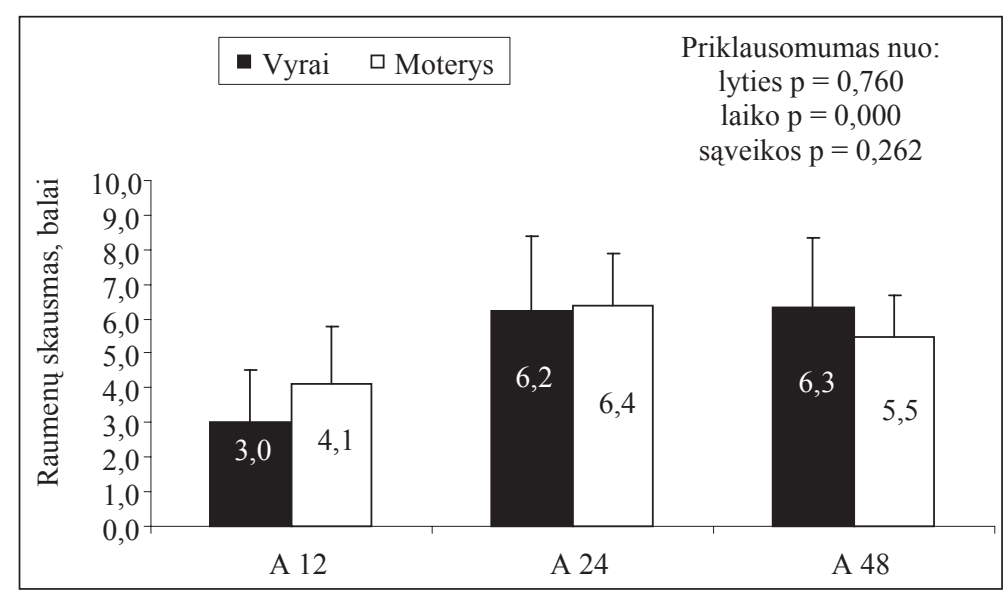

aktyvumo kitimą (5 pav.). Vyrų ir moteru kelio sulenkimo kampas buvo panašus ( $p>0,05 ; 2$ pav.).

\section{REZULTATU APTARIMAS}

Pagrindinè tyrimų išvada ta, kad vyrų ir moterų nuovargis ir atsigavimo kaita po didžiausio intensyvumo ekscentrinio-koncentrinio krūvio iš esmès nesiskiria, tačiau moterų kreatinkinazès aktyvumas praejjus $48 \mathrm{~h}$ po krūvio mažesnis.

Raumenų pažeidą, dẻl kurios pablogèja iš esmès visa žmogaus motorinès sistemos veikla (Byrne et al., 2004), lemia glaudžiai tarpusavyje susiję mechaniniai ir metaboliniai procesai (Warren et al., 2002). Mechaninis raumenų ištempimas gali pažeisti ne tik sarkomerus, bet ir sarkoplazmini tinklą, sarkolemą (Proske, Morgan, 2001). Metaboliniai procesai, turintys ittakos raumenu pažeidai, dažniausiai susiję su $\mathrm{Ca}^{2+}$ koncentracijos (Verburg et al., 2005) ir aktyvių deguonies formų pokyčiais (Child et al., 1999; Kendal, Eston, 2002). $\mathrm{Ca}^{2+}$ daugiau lemia baltymų hidrolizę, ypač vèlesnèse raumens atsigavimo fazėse (Warren et al., 2002; Verburg et al., 2005), ir jis labiau veikia viduląstelines raumenines skaidulas (sarkomerus). Aktyvios deguonies formos gali sukelti sarkolemos membranos lipidu peroksidinimą (Kendal, Eston, 2002). Mechaninių ir metabolinių procesų visuma sukelia uždegimini atsaką, kuris susijęs su vėluojančio raumenų skausmo pradžia (Byrne et al., 2004).

Raumenu jègos sumažejjimas pasireiškia iš esmès dviem aspektais: sutrinka nervo ir raumens elektromechaninis ryšys (Warren et al., 2002), kuri netiesiogiai rodo MDN (Skurvydas, Streckis, 1998; Skurvydas et al., 1999), ir raumenyje sumažèja sveikų sarkomerų kiekis, kurių būklę rodo nevalingų raumenų susitraukimo absoliučios jègos pokyčiai (Byrne et al., 2004). MDN rodo sumažejjusi $\mathrm{Ca}^{2+}$ išskyrimą iš sarkoplazminio tinklo, o šio nuo- vargio matavimai, esant skirtingam raumens ilgiui, leidžia įvertinti dar ir sarkomeru jautrumą $\mathrm{Ca}^{2+}$ (Westerblad et al., 1991). Tikejjomès, kad moteru raumenys turètų būti atsparesni MDN. Kodèl? Estradiolio poveikis raumenu nuovargiui ir atsigavimui vertinamas nevienareikšmiškai. Šis hormonas turi antioksidacinių savybių, estradiolio veikimo mechanizmas panašus ị vitamino $E$, jis stabilizuoja sarkolemą (Kendal, Eston, 2002). Antioksidantų vartojimas gali būti svarbi priežastis, mažinanti CK ištekejjimą i kraują (Bloomer et al., 2004). Be to, yra tyrimu, irodančių, kad aktyvios deguonies formos gali mažinti sarkomeru jautrumą $\mathrm{Ca}^{2+}$ (Moopanar, Allen, 2005). Kita vertus, estradiolis, kaip raumenu uždegimo slopiklis, gali kliudyti neutrofilų ir kitų su uždegiminiu atsaku susijusių citokinų infiltracijai ir tokiu būdu negatyviai veikti raumens regeneracija, nes manoma, kad uždegiminis atsakas susijęs su raumenų regeneracinėmis galimybėmis (Kendal, Eston, 2002; Smith et al., 2007). Mūsų tyrimo duomenys rodo, kad dauguma vyru ir moteru raumenu jëgos rodiklių atsigavimas panašus $(1,3,4$, 5 ir 6 pav.), nors moteru kreatinkinazès aktyvumas praejus 48 h po krūvio mažesnis. Galbūt tai rodo raumenų pažeidos specifiką, būdingą lyčiai (Sewright et al., 2008), nors, antra vertus, panašu, kad šis rodiklis nèra informatyvus vertinant raumenu pažeidos mastus; CK rodo daugiau jos kokybę (Clarkson, Hubal, 2002). Jeigu kreatinkinazès aktyvumas tiesiogiai rodytų raumens membranos būklę, tai galbūt turètų lemti ir MDN rodiklius, tačiau mūsų tyrimo duomenys rodo, kad lyties požiūriu MDN atsigavimo kaita buvo panaši.

Atsigavimo metu, kai raumenyse vyksta uždegiminiai procesai, jaučiamas subjektyvus raumenu skausmas, kuris susijęs su antriniu jègos mažejimu (Clarkson, Hubal, 2002). Po didžiausio ekscentrinio krūvio tiek vyrai, tiek moterys jaute panašų raumenų skausmą. Ši faktą patvirtina ir kitų 
tyrèjų darbai (Sayers, Clarkson, 2001; Sewright et al., 2008). Kai kurių tyrimų duomenys rodo, kad moterys netgi jautresnès pažeidai (Sewright et al., 2008). Visgi reikia paminèti, kad testuoti rankos lenkiamieji raumenys, kurie apskritai yra jautresni pažeidai ir jų atsigavimo trukmé, lyginant su kojų raumenimis, ilgesnè (Jamurtas et al., 2005). Atrodytų, kiek stebètini tokie dèsningumai. Vienas iš bendraautoriu kitu tyrimu konstatavo faktą, kad nuovargio tempai krūvio metu nuo lyties nepriklauso (Hubal et al., 2008). Mūsų tyrimo duomenys parodé, kad iš esmès tiek vyrų, tiek moterų nuovargio rodikliai panašūs. Tai rodo tiek MVJ, kuri laikoma vienu informatyviausių raumenu pažeidos rodikliu, matavimai (Clarkson, Hubal, 2002), tiek nevalingų raumens susitraukimų santykinès jègos, tiek šuolio aukščio iš fiksuotos padèties pokyčiai. Toks šuolių būdas buvo pasirinktas tam, kad nesisumuotu tampriuju ir kontraktilinių elementu jèga, ir galbūt aiškiau būtų matoma pastarujų komponentų būklè po fizinio krūvio (Muckus, Čižauskas, 2006). Be to, histologiniai tyrimai ( $\mathrm{Z}$ disko pakitimai) taip pat parodè, kad po raumenu pažeidą sukèlusių fiziniu jègos pratimų statistiškai reikšmingo skirtumo lyties požiūriu nèra (Stupka et al., 2001). Vyrų ir moterų kelio sulenkimo kampas krūvio metu buvo panašus. Tai svarbus raumenų pažeidos veiksnys, o didesnè raumenų ištempimo amplitude lemia ir pažeidos dydi (Child et al., 1998; McHugh, Pasiakos, 2004).

\section{IŠVADOS}

Vyru ir moteru raumenu nuovargis ir atsigavimo kaita po ekscentrinio-koncentrinio krūvio iš esmès nesiskiria, tačiau moterų kreatinkinazès aktyvumas praejus $48 \mathrm{~h}$ po krūvio yra mažesnis.

\section{LITERATŪRA}

Bar, P. R., Amelink, G. J., Oldenburg, B., Blankenstein, M. A. (1988). Prevention of exercise-induced muscle membrane damage by estradiol. Life Sciences, 42 (26), $2677-2681$.

Bloomer, R. J., Goldfarb, A. H., McKenzie, M. J., You, T., Nguyen, L. (2004). Effects of antioxidant therapy in women exposed to eccentric exercise. International Journal of Sport Nutrition and Exercise Metabolism, 14 (4), $377-388$.

Bosco, C., Komi, P. (1979). Mechanical characteristics and fiber composition of human leg extensors muscles. European Journal of Applied Physiology, 41, 275-284.

Byrne, Ch., Twist, C., Eston, R. (2004). Neuromuscular function after exercise-induced muscle damage. Sports Medicine, 34 (1), 49-69.

Child, R., Brown, S., Day, S. et al. (1999). Changes in indices of antioxidant status, lipid peroxidation and inflammation in human skeletal muscle after eccentric muscle actions. Clinical Science, 96, 105-115.

Child, R. B., Saxton, J. M., Donnely, A. E. (1998). Comparison of eccentric knee extensor muscle actions at two muscle lengths on indices of damage and angle-specific force production in humans. Sports Science, 16 (4), $301-308$.

Clarkson, P. M., Hubal, M. J. (2002). Exercise-induced muscle damage in humans. American Journal of Physical Medicine and Rehabilitation, 81, 52-69.

Feng, X., Li, G., Wang, Sh. (2004). Effects of estrogen on gastrocnemius muscle strain injury and regeneration in female rats. Acta Pharmacologica Sinica, 25 (11), $1489-1494$.

Hubal, M. J., Rubinstein, S. R., Clarkson, P. M. (2008). Muscle function in men and women during maximal eccentric exercise. Journal of Strength and Conditioning Research, 22 (4), 1332-1338.

Jamurtas, A. Z., Theocharis, V., Tofas, T. et al. (2005). Comparison between leg and arm eccentric exercises of the same relative intensity on indices of muscle damage.
European Journal of Applied Physiology, 95 (2-3), $179-185$.

Jones, D. A., Newham, D. J., Clarkson, P. M. (1987). Skeletal muscle stiffness and pain following eccentric exercise of the elbow flexors. Pain, 30 (2), 233-242.

Kendal, B., Eston, R. (2002). Exercise-induced muscle damage and potential protective role of estrogen. Sports Medicine, 32 (2), 103-123.

McHugh, M. P., Pasiakos, S. (2004). The role of exercising muscle length in the protective adaptation to a single bout of eccentric exercise. European Journal of Applied Physiology, 93 (3), 286-293.

Moopanar, T. R., Allen, D. G. (2005). Reactive oxygen species reduce myofibrillar $\mathrm{Ca}^{2+}$ sensitivity in fatiguing mouse skeletal muscle at $37^{\circ} \mathrm{C}$. Journal of Physiology, 564 (1), 189-199.

Muckus, K., Čižauskas, G. (2006). Šuolio aukštis rodo kojų tiesiamujų raumenu staigiają jègą: mitas ar tikrové? Ugdymas. Küno kultūra. Sportas, 3 (62), 43-48.

Proske, U., Morgan, D. L. (2001). Muscle damage from eccentric exercise: Mechanism, mechanical signs, adaptation and clinical applications. Journal of Physiology, 537 (2), 333-345.

Sayers, S. P., Clarkson, P. M. (2001). Force recovery after eccentric exercise in males and females. European Journal of Applied Physiology, 84, 122-126.

Sewright, K. A., Hubal, M. J., Kearns, A. et al. (2008). Sex differences in response to maximal eccentric exercise. Medicine and Science in Sports and Exercise, 40 (2), 242-251.

Skurvydas, A., Streckis, V. (1998). Vaikų raumenų mažų dažnių nuovargis atliekant ekscentrinius-koncentrinius fizinius pratimus. Medicina, 34 (10), 1011-1017.

Skurvydas, A., Zachovajevas, P., Streckis, V. (1999). Raumenų mažų dažnių nuovargio ir potenciacijos ypatumai atliekant kartotinius ir nenutrūkstamus šuolius maksimaliu intensyvumu. Ugdymas. Kūno kultūra. Sportas, 2 (31), 67-78. 
Smith, L. L., Semple, S. J., McKune, A. J. et al. (2007). Changes in neutrophil count, creatine kinase and muscle soreness after repeated bouts of downhill running. SAJSM, 19 (3), 86-93.

Streckis, V., Skurvydas, A., Ratkevicius, A. (2007). Children are more susceptible to central fatique than adults. Muscle Nerve, 36 (3), 357-363.

Stupka, N., Tarnopolsky, M. A., Yardley, N. J., Philips, M. (2001). Cellular adaptation to repeated eccentric exerciseinduced muscle damage. Journal of Applied Physiology, 91, 1669-1678.

Tiidus, P. M. (2000). Estrogen and gender effects on muscle damage, inflammation, and oxidative stress. Canadian Journal of Applied Physiology, 25 (4), 274-287.

Verburg, E., Murphy, R. M., Stephenson, D. G., Lamb, G. D.
(2005). Disruption of excitation-contraction coupling and titin by endogenous $\mathrm{Ca}^{2+}$-activated proteases in toad muscle fibres. Journal of Physiology, 564 (3), 775-789.

Warren, G. L., Ingalls, C. H. P., Lowe, D. A., Armstrong, R. B. (2002) What mechanisms contribute to the strength loss that occurs during and in the recovery from skeletal muscle injury. Journal of Ortopedic and Sports Physical Therapy, 2 (32), 58-64.

Westerblad, H., Lee, J. A., Lannergren, J., Allen, D. G. (1991). Cellular mechanisms of fatigue in skeletal muscle. American Journal of Physiology, 261 (2 pt 1), 195-209.

Yoon, T., Schlinder, D. B., Griffith, E. E., Hunter, S. K. (2007). Mechanisms of fatique differ after low- and highforce fatiguing contractions in men and women. Muscle Nerve, 11, 39-48.

\title{
DOES MAXIMAL INTENSITY ECCENTRIC-CONCENTRIC PHYSICAL EXERCISE SIMILARLY EFFECT THE MOTOR SYSTEM OF MEN AND WOMEN?
}

\author{
Giedrius Gorianovas ${ }^{1}$, Vytautas Streckis ${ }^{1}$, Albertas Skurvydas ${ }^{1}$, Sigitas Kamandulis ${ }^{1}$, \\ Vaidas Mickevičius ${ }^{2}$ \\ Lithanian Academy of Physical Education ${ }^{1}$, Kaunas Technical College ${ }^{2}$, Kaunas, Lithuania
}

\begin{abstract}
The aims of the research was to assess if there was a sex dependence in human motor system fatigue and recovery after maximal intensity eccentric-concentric physical workload.

Research group included healthy, physically active and nine $20.8 \pm 1.9$ year-old men (height $181.9 \pm$ $5.9 \mathrm{~cm}$, weight $82.6 \pm 10.0 \mathrm{~kg}$ ) and nine $22.0 \pm 3.9$ year-old women (height $166.6 \pm 5.2 \mathrm{~cm}$, weight $62.6 \pm$ $5.5 \mathrm{~kg}$ ). who voluntarily agreed to participate in the study.

The methods of the research were as follows: indirect muscle damage indexes were assessed before the workload and 10,60 min, 24 and 48 hours after it; maximal voluntary contraction (MVC) and involuntary (20 and $100 \mathrm{~Hz}$ electrostimulation evoked) quadriceps muscle power during long-term (LL) and short-term (SL) muscle stretch length (when the knee flexion angle was $90^{\circ}$ and $60^{\circ}$ ), low frequence fatique (LFF) by 20 / 100 ratio were assessed; jump height (h) from a fixed starting position; before the workload, 24 and 48 hours after the workload creatinkinase activity was assessed, and 12, 24 and 48 hours after the workload subjective muscle soreness was assessed. Physical workload applied was 100 jumps every $20 \mathrm{~s}$, jumping from $40 \mathrm{~cm}$ height platform and squatting at $90^{\circ}$ angles, then skipping at maximally possible height. Knee flexion angle (KFA) was assessed during the workload.

Results of the research: after a workload men and women's fatigue indexes did not show a statistically significant difference $(\mathrm{p}>0.05)$ : comparing with the onset indexes at LL mens MVC was $62.9 \pm 14.1 \%$, SL reached $64.4 \pm 14.1 \%$, women's MVC $-71.7 \pm 8.3 \%$ and $65.7 \pm 9.3 \%$; jump height for men was $83.6 \pm$ $7.2 \%$, for women was it $80.3 \pm 6.5 \%$; LFF for men $-59.3 \pm 20.9 \%$ during LL and $33.8 \pm 14.8 \%$ during SL, accordingly for women $-68.7 \pm 17.5 \%$ and $43.4 \pm 16.4 \%$. Subjective men and women's muscle soreness was similar $(\mathrm{p}>0.05)$. A voluntary and involuntary muscle contraction power change during recovery period was not dependant on sex. It was determined that during our research 48 after workload, women's creatinkinase activity comparing to the one of men was statistically significantly lower $(\mathrm{p}<0.05)$.

Conclusions: men and women's muscle fatigue and recovery dynamics after maximal intensity eccentricconcentric workload does not significantly vary, but women have lower creatinkinase activity in time point 48 hours after physical workload.
\end{abstract}

Keywords: sex, eccentric-concentric exercise, fatigue and recovery.

Gauta 2010 m. birželio $30 \mathrm{~d}$.

Received on June 30, 2010

Priimta $2010 \mathrm{~m}$. lapkričio $18 \mathrm{~d}$.

Accepted on November 18, 2010
Giedrius Gorianovas

Lietuvos kūno kultūros akademija

(Lithuanian Academy of Physical Education)

Sporto g. 6, LT-44221 Kaunas

Lietuva (Lithuania)

Tel +37068549283

E-mail giegorster@gmail.com 